\title{
9
}

\section{WTO commitment: further marketisation and trade liberalisation}

\author{
Jiadong Tong
}

Since becoming a member of the World Trade Organization (WTO) in December 2001, China has been carrying out the commitments included in the 'Protocol on the Accession of the People's Republic of China'. This has required major steps on unification and transparency of its trade system, and expanding market access. China's accession to the WTO has meant that rapid government reform has simplified rationalisation of government functions, liberalised trade and increased marketisation. Market forces have been increasingly important in resource allocation. Rapid development of the private economy is giving a new impetus to economic growth, but some difficulties concerning the modification of laws and regulations, and some tensions concerning other aspects of marketisation, remain.

\section{MARKET REFORM AND TRADE LIBERALISATION}

China has further advanced its marketisation and trade liberalisation according to the Protocol on the Accession since it entered the WTO. Two elements contained in the Protocol are liberalisation of foreign trade and continued marketisation. Progress has been made in both areas, showing the sincerity of China's commitment.

On trade liberalisation, China produced many legal documents concerning unification and transparency of trade systems. This represents a legal guarantee of the unification and execution of its trade system. Over 30 departments affiliated 
with the State Department revised related economic laws and regulations concerning foreign affairs. By 2002, China had nullified 830 laws and regulations and revised 325. At the same time, central government required local government to reconsider all of its existing regulations. Local government sorted out over 190,000 laws and regulations. In order to meet the requirements of the WTO, China drafted a series of laws and regulations consistent with WTO rules, such as the new 'antidumping ordinance', 'anti-subsidy ordinance', 'safeguard measure ordinance' and so on. The sorting out and revision of these legal documents provides a legal guarantee for the unification of China's foreign trade management.

Before 1978, China was a planned economy. Foreign trade policy and management was only a part of the government's economic planning management. The government's foreign trade management had to submit to economic planning needs. There was no effective foreign trade law that regulated trading activities. Foreign trade management, like other government functions, was subject to administrative command. China's accession to the WTO requires China to change the way in which government arranges and manages foreign trade, so that a uniform standard based on the law for foreign trade management can be established.

After 1978 , China gradually recognised that the only way to expedite economic growth was by opening to the outside world and making full use of its economic resources and markets. China also established four coastal areas as special economic zones. Central government granted corresponding rights and power to these regions, and implemented favourable policies concerning the introduction of foreign capital. As a result, variations in trade policy were created among different regions.

Since accession to the WTO, special zones, such as Shenzhen, Zhuhai, Xiamen and Hainan provinces, lost their special privileges regarding foreign trade policy. They must carry out the same uniform foreign trade policy as other regions, and can no longer adopt more favourable policies to attract foreign capital.

The second requirement of trade liberalisation is to enlarge market entry for foreign products. In the protocol for China's accession to WTO, China consented to eliminate trade barriers gradually and to make it convenient to import foreign goods. China affirmed a schedule of tariff and non-tarriff measures. Part of these tariff concessions was the reduction of custom duties for over 5,300 kinds of goods in 2002. As a result, China's average import tariff level decreased from 15.8 per cent in 2001 to 12.1 per cent in 2002 . In 2003, China will have an average import tariff level of 11.5 
per cent. The downward trend will continue. The average tariff levels of industrial products and farm produce will be cut 7.2 per cent and 9.6 per cent respectively, and the import tariff of over 110 kinds of goods will drop to zero in 2003. Tariff concessions for some goods were more dramatic. For example, tariffs for cars were cut by nearly 100 per cent on the eve of China's accession to the WTO.

As part its commitments to the WTO, China also reduced non-tariff barriers. During 2001-2, China's annual import permits and quotas for over 800 kinds of goods were reduced or abolished. The list included open-tender management of eight kinds of important goods such as cereal, wool, cotton, chemical fertilisers, and so on, which, under the planned economy, were classed as primary products critical to the national economy and the people's livelihood. The government also limited the scope of state trading or government monopoly on specified products.

To facilitate FDI, the government implemented the Interim Provisions on Guiding Foreign Investment Direction in 2002. At the same time, the new Catalogue for the Guidance of Foreign Investment Industries divided foreign investment projects into four groups: the encouraged, the allowed, the restricted and the prohibited. The amount of encouraged foreign investment projects increased from 186 to 262, and the amount of the restricted decreased from 112 to 75 in 2002. Commerce, banking and insurance, as well as foreign trade, tourism, telecommunications, transport, accounting, auditing and other industries were all opened up further. China will open these industries completely after some years of transition.

China has gradually opened trade rights and distribution rights to the outside world. Sales of 22 foreign-owned retailing enterprises in 2002 were estimated to make 100.9 billion yuan and to constitute more than 40 per cent of gross sales among China's top 100 chain retailers. The total number of foreign-owned stores rose to 2,285, accounting for 13.4 per cent of the total number of stores of China's top 100 chain retailers. China authorised 60 foreign banks to operate foreign exchange business with no limit on region or clients. Fifty-three banks were authorised to conduct RMB business in nine cities, such as Shanghai and Shenzhen. China granted market access to six foreign insurance corporations in 2002. At present, 34 insurance corporations from 12 countries and regions have established 54 business operation institutions in China.

China has established legal safeguards for intellectual property. On the eve of accession to the WTO in 2001, China passed a series of laws and regulations concerning the protection of intellectual property, for example, the Copyright Law of 
the People's Republic of China and the Trademark Law of the People's Republic of China, as well as regulations governing patent law and the protection of computer software.

China was rigorous in keeping the new legal system for protection of intellectual property consistent with the related clauses of the WTO and to fulfil the commitments in the protocol on China's accession to WTO. As a result, the number of applications for patents increased by 24 per cent in 2002 over 2001. In 2002, the patent department received 252, thousand applications for patents-205 thousand domestic applications, accounting for 81.3 per cent of the total, and 47,236 foreign applications, accounting for the remaining 18.7 per cent. In the same period 132,401 patent warrants were issued, of which 112,088 were domestic and 20,313 foreign. The total amount of applications for trademarks in 2002 was 372,000 , an increase of 37 per cent from 2001. In the meantime, central and local government strengthened investigation into intellectual property right infringementsand intensified the penalties for such infringements.

Collective, private and other non-state-owned economies have increased in China. Fixed asset investments from these now comprise over 40 per cent of the total in 2002 and are increasing at 30 per cent per annum. The $16^{\text {th }}$ National Congress of the Communist Party of China endorsed the government policy of encouraging development of the private economy. During the initial stage of economic reform, the state sector accounted for more than 90 per cent of the total. If the production of the collective economy production is included, the share of the state sector would have been around 98 per cent at that time. The government has taken a gradual approach to privatising the state-owned enterprises (SOEs). China's accession to WTO will accelerate the process by promoting the role of the non-state sector in the national economy.

In 2002, the non-state sector, including foreign firms, played an important role in China's foreign trade (Table 9.1). SOE exports made up less than one-third of total exports and imports made up slightly more than one-third of all imports. Imports and exports of foreign-owned enterprises made up about half each. The growth of foreign trade of private enterprises has grown the most rapidly, followed by that of foreign owned enterprises, although the weight of private enterprises in total imports and exports is still relatively small. The protocol on China's accession to WTO stipulates that foreign trade rights must be opened after three years of transition. There is no doubt that this will increase the proportion of foreign trade attributable to 
foreign-owned and private enterprises as the government grants more and more trading rights to private firms. The system is also changing from the examination and approval system to a standard registration system for conducting foreign trade.

To increase market competition, the government has started the process of breaking up state monopolies in some areas, for example, it has divided the telecom communication industry into northern and southern corporations. The north, the China Net Communication Group, is in charge of the telecom business of ten provinces in the north, while the former China Telecom is in charge of 21 provinces in the south. These two corporations compete with each other and have the right to do business in their counterpart's regions. China has also reconstructed the civil aviation industry, establishing three big airline companies-Air China, China Southern Airlines and China Eastern Airlines-in order to improve services and introduce competition.

In the fields of retailing, insurance and other traditional competitive industries, increased competition has occurred because of the liberalisation of services trade, increased private sector participation, and the accelerated reform of SOEs. China has enacted related laws for improving the environment of market competition-for example, in 2002 over ten laws diminishing unfair-competition were legislated.

The Chinese government now has less power to participate directly in the economy. According to institutional reform decided in the $16^{\text {th }}$ National People's Congress of the People's Republic of China, China incorporated and reformed ministries and commissions to make them more compatible with the operation of the market system.

Table 9.1 Imports and exports by different types of enterprise, 2002

\begin{tabular}{|c|c|c|c|c|}
\hline \multirow[b]{2}{*}{$\begin{array}{l}\text { Nature of } \\
\text { enterprise }\end{array}$} & \multicolumn{2}{|c|}{ Exports } & \multicolumn{2}{|c|}{ Imports } \\
\hline & $\begin{array}{c}\text { Value } \\
\text { (US\$100m) }\end{array}$ & $\begin{array}{l}\text { Year-on-year } \\
\text { growth rate } \\
\text { (per cent) }\end{array}$ & $\begin{array}{c}\text { Value } \\
\text { (US\$100m) }\end{array}$ & $\begin{array}{l}\text { Year-on-year } \\
\text { growth rate } \\
\text { (per cent) }\end{array}$ \\
\hline State-owned & 1228.6 & 8.5 & 1144.9 & 10.6 \\
\hline Foreign-owned & 1699.4 & 27.6 & 1602.7 & 27.4 \\
\hline Collective & 188.6 & 32.6 & 94.8 & 18.5 \\
\hline Private & 137.8 & 159.5 & 95.6 & 180.9 \\
\hline Others & 1.3 & -12.5 & 14.1 & -49.7 \\
\hline Total & 3255.7 & 22.3 & 2952.0 & 21.2 \\
\hline
\end{tabular}

Source: China Customs Administration, 2002. China Customs Statistics, Beijing. 
In particular, the State Assets Management Commission has been established to change the function of government from running SOEs to managing state-owned assets. The change will create the institutional condition for the government to retreat from microeconomic management of the economy. The State Planning Commission has been renamed the State Development and Reform Commission and its new responsibility is to reform economic management systems and to improve economic development. The government annulled the former State Economic and Trade Commission and Ministry of Foreign Trade and Economic Cooperation, and established the Ministry of Commerce to unite domestic and foreign trade and manage the economy as its primary function.

The adjustment of these ministries and commissions is not simply a change of names, but a significant reform by the government in the course of marketisation and liberalisation. It represents an important step towards development of market institutions and fundamental transformation of governmental functions. Following the central government's lead, local governments will also initiate institutional change and reform, laying an institutional foundation for China's marketisation

China has focused its attention on the following areas in the course of marketisation

- the privatisation of SOEs and enhancement of the private economy's role in national economy

- the elimination of state monopoly and creation of a free competitive environment

- the creation of a legal and regulatory system to protect property rights and support the market order

- institutional reform

- the transformation of government functions. When this process is finished China's transition from a nonmarket economy to a market economy country will be complete.

\section{THE WTO AND CONTINUED REFORM}

Marketisation and liberalisation have been occurring since reform started in the late 1970s. The process has been enhanced by China's efforts to become a member of the WTO. China has successively lowered its general tariff level since putting forward its application to the WTO (which was called re-entry into GATT) in 1986, and many tariffs were cut to a large extent (Table 9.2).

China's gradual tariff reductions were implemented with GATTMTO entry in mind, but at the same time, however, China also wished to benefit from an open economy 
policy. Apart from tariff reductions, non-tariff barriers also decreased markedly. The main achievement was a decrease in quota and license management. From 1992 to 2000 , the number of goods subject to import licenses and quotas decreased by two-thirds, and the number of enterprises that had foreign trade rights increased from approximately 30,000 to more than 350,000 .

Liberalisation has been a driving force in China's economic growth and development. China's dependence on foreign trade increased from 5 per cent at the beginning of reform to 50 per cent in 2000 . Authorities recognise that trade liberalisation in a nonmarket economy should be based on domestic marketisation in order for the liberalisation program to be effective.

China's accession to the WTO marked a new phase of marketisation and liberalisation in China, in which crucial parts of the reform program, such as government reform itself were carried out. The WTO not only exerts strong external pressure for reform, but also has restrictions on the content of marketisation and trade liberalisation, for example, its 'rewards and punishment' for compliance or

Table 9.2 Selected Chinese tariff rates prior to WTO accession, 1987-2000 (per cent)

\begin{tabular}{|c|c|c|c|c|c|}
\hline & 1987 & Dec 1992 & Dec 1993 & Apr 1996 & Dec 1997 \\
\hline Average tariff rate & 43.1 & 39.9 & 36.4 & 23.0 & 17.0 \\
\hline Agriculture & 37.7 & 34.5 & 34.4 & 27.2 & 17.2 \\
\hline Mining and quarrying & 22.0 & 20.2 & 20.4 & 6.0 & 3.4 \\
\hline Consumption goods in manufacturing & 65.8 & 63.9 & 60.5 & 35.5 & 25.3 \\
\hline Capital goods manufacturing & 29.5 & 36.2 & 32.9 & 21.6 & 17.2 \\
\hline Intermediate input in manufacturing & 28.8 & 21.7 & 29.0 & 17.1 & 15.1 \\
\hline Petroleum refining products & 17.6 & 16.0 & 13.9 & 8.1 & 7.6 \\
\hline $\begin{array}{l}\text { Raw chemical materials and } \\
\text { chemical products }\end{array}$ & 26.6 & 26.2 & 23.3 & 14.1 & 11.4 \\
\hline $\begin{array}{l}\text { Building materials and other nonmetal } \\
\text { products }\end{array}$ & 46.4 & 44.5 & 39.9 & 26.9 & 18.4 \\
\hline Products of smelting and pressing & 40.4 & 44.5 & 39.9 & 20.9 & 10.4 \\
\hline $\begin{array}{l}\text { of ferrous metals } \\
\text { Products of smelting and pressing }\end{array}$ & 13.3 & 14.1 & 14.3 & 9.6 & 9.1 \\
\hline of nonferrous metals & 16.2 & 16.2 & 15.4 & 10.0 & 7.8 \\
\hline Metal products & 43.0 & 42.8 & 38.5 & 20.4 & 13.5 \\
\hline
\end{tabular}

Source: Jin Xiangrong and Lin Chengliang, 1999. 'Positive analysis of China's all previous tariff adjustments and their effective protection structure', World Economy, 26(1):28-34. 
non-compliance. The protocol includes procedures to evaluate the process of China's market economy reform, supervise trade liberalisation and the transition on the part of marketisation. Under this system, China's economic reforms need to advance more quickly, especially in the area of reform and privatisation of SOEs, and in legislation and regulation.

However, while the construction of the legal system has been advancing rapidly, China is confronted with the problem of implementing the new laws. In the past five years, the Standing Committee of the National People's Congress (NPC) of China has passed 113 laws, a large number in the history of China's legal system. But passing a law is only part of the process; implementation is critical. Under the planned economic system, the administration of government mainly relied on various kinds of administrative decrees or regulations, and law was not the main foundation for the behaviour of individuals, enterprises and the government. Government officials and law enforcement authorities are not used to changing their long-enduring habit of administrative control, and business entities and residents are not accustomed to appealing to laws to defend their rights.

A second problem is that, in the course of implementation of the commitments in the protocol for China's accession to the WTO, some neglected links remain in terms of the functions and coordination of the government institutions which implement the commitments. The solution lies in strengthening the institutional reform. This was one of the key reform priorities put forward by the central government in 2003.

A third issue is that new trade protections may emerge to carry out China's commitments to the WTO, especially concerning efforts to normalise its trade protection measures. This could happen if China adopts transitional administrative measures that are not consistent with the basic principles of the WTO. Disputes may emerge as a result.

China faces some other problems as its participation in economic globalisation grows. For example, China could face some potentially detrimental treatment from a non-market economy country. The protocol on China's accession stipulates that the a member can adopt special safeguard measures against China. This clause is valid for 12 years. Such a clause makes a provision for every member to take certain measures if faced with increasing imports from China. It would be a shame for China to suffer unduly from other countries protecting themselves because this could persuade the Chinese government to take corresponding measures to protect 
its own industries. With an increasing degree of marketisation in China resulting from the reform and liberalisation, it would be advantageous to both Chinese and foreign firms when China is treated formally as a market-economy.

\section{PROSPECTS}

China's accession to the WTO has brought new opportunities for domestic reform and economic development. It provides favourable conditions for China and other countries in the world.

China is committed to lowering its tariff barriers gradually to an average tariff level of 8.9 per cent and to abrogating non-tariff barriers that contravene the WTO principles. China will push its trade liberalisation further after the new round of multilateral trade negotiations.

Besides multilateral commitments, China recently paid particular attention to the development of bilateral free trade cooperation in the hope that such a movement would further its China's liberalisation program. China has signed an agreement on the foundation of a free trade area with ASEAN, hoping to gain free trade between China and 10 countries of ASEAN within 10 years.

China's accession to the WTO has resulted in a significant increase in the overall scale of China's foreign trade. However, this also highlights the fact that protection measures from its trading partners are highly likely. These measures will have a negative impact on China's foreign trade, dampening the growth of its exports. Trade disputes are not conducive to the interests of China or its trading partners.

Trade liberalisation has had a significant effect on Chinese trade only after the achievement of a certain degree of marketisation in the Chinese economy. China has pinned its marketisation to trade liberalisation under the WTO. In the long run, the processes of marketisation and trade liberalisation will reinforce each other, bringing China closer to its goal of establishing a market system.

\section{CONCLUSIONS}

Since China's accession to WTO, China has reduced its import tariffs and abolished a series of non-tariff barriers. Elements of a private economy have emerged, and the state-owned sector has shrunk. China has reformed the government organisations and institutions to make them consistent with the requirements of the WTO. All these reforms have created the conditions necessary for the mechanism of market economy to operate successfully. 
Accession to WTO is a landmark in China's marketisation and trade liberalisation. Reforms will continue now that China has acceded to the WTO. This will continue to be a gradual process, and there will be resistance and problems. But the transient pain of adjustment and transition are unavoidable if China is to feel the benefits of marketisation and trade liberalisation.

\section{REFERENCES}

Chen Zongsheng, 1999. The Process of Marketization in the Chinese Economic System, People's Publishing House, Shanghai.

China Customs Administration, 2002. China Customs Statistics, Beijing.

Fan Gang, 1996. Political_Economic Analysis on Gradual Reform, Far Eastern Publishing House, Shanghai.

Neary, J.P., 1993. Domestic Distortion and International Trade, Policy Research Working Paper 1163, World Bank, Washington, DC.

Drysdale, P. and Ligang Song (eds), 2000. China's Entry to the WTO, Routledge, London and New York.

Qian Yingyi, 1999a. The Process of China's Market Transition (1978-1998): the evaluation, historical, and comparative perspective, Paper prepared for the Journal of International Economics Symposium, 'Big-Bang-Transformation of economic systems as a challenge to new institutional economics, Wallerfangen/Saar, 911 June.

Garnaut, R. and Ligang Song, 2002. China 2002: WTO entry and world recession, Asia Pacific Press, Canberra.

Sheng Bin, 2002. A Political Economic Analysis on Chinese Foreign Trade Policy, People's Publishing House, Shanghai.

Tong Jiadong, 1996. 'The reform of the Chinese foreign trade regime', Nankai Journal, 13(3):30-3.

- 2002. Trade Liberalization, Trade Protection and Economic Interest, Economic Science Publishing House, Beijing.

Wang Guang $\mathrm{Pu}$, 1999. Tariffs: theory, policy and practice, Foreign Economic and Trade University Press, Beijing.

World Bank, 1987, 2001, 2002. World Development Report, World Bank, Washington, DC. 